\title{
Contents of Volume 12
}

From the Editors

1,203

Gaberell Drachman, Dag T.T. Haug, Brian D. Joseph, and Anna Roussou

Introduction

Corien Bary and Rob van Der Sandt

\section{Articles}

Clause Intertwining and Word Order in Ancient Greek

Rutger J. Allan

Tense in Ancient Greek Reports

Corien Bary

A Semantics for the Particle $\alpha \dot{\alpha}$ in and outside Conditionals in Classical Greek

Jana E. Beck, Sophia A. Malamud, and Iryna Osadcha

Greek Anaphora in Cross-Linguistic Perspective

Paul Kiparsky

Switches between Direct and Indirect Speech in Ancient

Greek

Emar Maier

Does Ancient Greek Have a Word for 'No'? The Evidence from oủxoúv

... oủ Questions

Albert Rijksbaron

A Source of Variation: A Corpus-Based Study of the Choice between $\dot{\alpha} \pi \dot{o}$ and $\varepsilon \dot{x}$ in the NT Greek Gospels

Peter de Swart, Hanne M. Eckhoff, and Olga A. Thomason

Perfect Periphrases in Post-classical and Early Byzantine Greek:

An Ecological-Evolutionary Account

Klaas Bentein 
The Interaction between Presupposition and Focus: Classical Greek Wh-Exclamatives

Richard Faure

On the Verbal Complements of Aspectual Verbs

Nikolaos Lavidas and Gaberell Drachman

\section{Discussion Notes}

Response to the Review by Silvia Luraghi of Greek Prepositions: From Antiquity to the Present

Pietro Bortone

Reply to Pietro Bortone

$198-201$

Silvia Luraghi

\section{Book Reviews}

Stéphanie J. Bakker, The Noun Phrase in Ancient Greek. A Functional Analysis of the Order and Articulation of NP Constituents in Herodotus

Jerneja Kavčič

Frank Scheppers, The Colon Hypothesis. Word Order, Discourse Segmentation and Discourse Coherence in Ancient Greek

Eirik Welo 